\title{
An unfinished reformation: The persistence of gender-exclusive language in theology and the maintenance of a patriarchal church culture
}

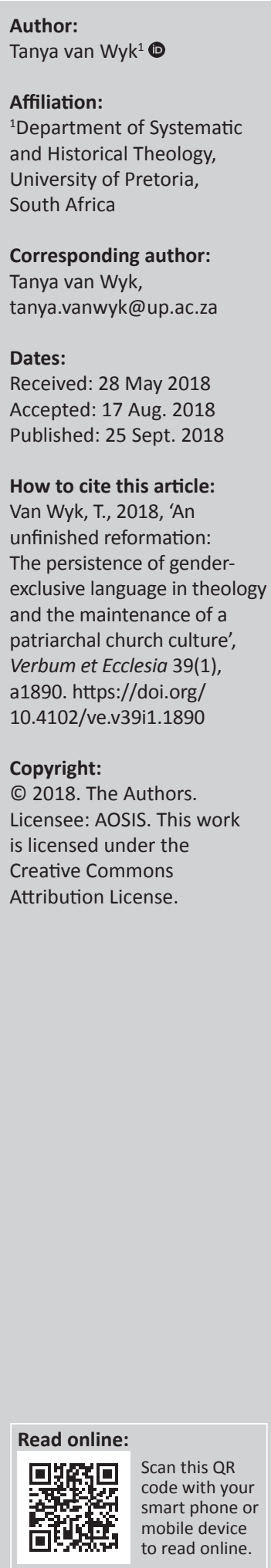

For more than four decades, a variety of theologians from different backgrounds and different points of departure have argued that the language we use in reference to God and humanity should be inclusive of different genders and that exclusive language has harmful consequences. Yet, it persists because of, in part, the argument that inclusive language, specifically in reference to God, is forced and awkward and also because it is considered as an existential concern to only a minority. This article examines the persistence of genderexclusive language in theology as an unfinished dimension of church reformation. This includes the language of theological imagery, metaphors, grammar, theological research, books used to teach theological students, academic papers at conferences, sermons, devotional texts, liturgies and church hymns. In reference to a justification of genderexclusive language made by theologian Klaus Nürnberger in one of his recent (2016) publications, this article will provide an overview of the issues involved in debate about theology, language and gender in order to illustrate that exclusive language and its effects have become normalised, and therefore it is invisible. Therefore, the time has come for a status confessionis about gender-exclusive language.

Intradisciplinary and/or interdisciplinary implications: This article brings theological discourse into discussion with linguistic studies, gender studies, hermeneutic studies and theological anthropology. It also explores the relationship between religion and religious language in general. It impacts systematic theological conceptions of 'God' and challenges metaphysical descriptions of God.

\section{Introduction: 'A brief word about gender'}

In January 2018, a symposium in honour of the theological contribution of Klaus Nürnberger was presented at the Faculty of Theology and Religion at the University of Pretoria. The focus was on his 2016 comprehensive volumes on systematic theology (Nürnberger 2016a, 2016b). While reading through different sections of his work in order to decide which aspect to reflect on, I noticed a peculiar phenomenon. Male personal pronouns (he, him, his) that are used in reference to God are placed between inverted commas. I paged to the introduction to search for an explanation for this phenomenon. In a section titled, 'A brief word about gender' (Nürnberger 2016a:xxiv-xxii), I found not only an explanation for the use of the inverted commas, but also a justification for the use of male pronouns. In summary, the following is stated:

- It is very difficult to avoid sexist language with regard (in reference) to God.

- Historical sensitivity prevents the author from changing the wording of historical documents.

- The biblical scriptures were written for people living in a patriarchal social context.

- The task at hand is not to change the scriptures but to 'translate their message from their original ancient world views and contexts into contemporary ones'.

- 'God' is a male noun. Replacing the relevant pronouns (he, his, him and himself) with the noun 'God' hides the (language) problem without solving it.

- The concept of God is male and therefore the reader will still associate a male gender designation with the noun functioning as a pronoun.

- The practice of replacing the male pronouns with 'God' leads to artificial linguistic constructs and awkward sentences. For this reason, male pronouns are placed in 'inverted commas' (pp. xxi-xxii).

There are aspects of Nürnberger's introductory explanation that can be acknowledged, namely that language and grammar choices (linguistics) can be a specialised and a technically complicated endeavour. It is also indeed a reality that biblical scriptures originated in a patriarchal social 
context. The rest of the statements, however, present some challenges and are underpinned by notions that require broader consideration and argument.

Firstly, 'historical sensitivity' is not only about preservation, that is, changing documents or not. With regard to biblical scriptures, it includes an awareness of epistemological and hermeneutical concerns of 'how' and 'why' 'history' (the document) was recorded in the way it was and the 'translation' of it for today. Keeping male pronouns in reference to God in a theology book, which is not the Bible, does not manage to 'translate their message (biblical texts) from their original ancient world views and contexts into contemporary ones' (cf. Nürnberger 2016a:xxiv). Secondly, the assumption that all readers will associate a male gender designation with the noun 'God' is arguable, especially with regard to those persons (readers) who are part of a religious context. Finally, as will be pointed out in the remainder of this article, the use of the noun 'God' instead of a male pronoun is not 'artificial' and from an ethical perspective, it is a question if it is more important to have a sentence that 'flows' linguistically than one that is linguistically problematic because it is inclusive. ${ }^{1}$

Nürnberger's work is by no means the only example of persistent gender-exclusive language in theology and in systematic theology in particular. In 2015, Anthony Thiselton's new volume, Systematic theology, was published, in which he uses male-gendered pronouns in reference to God. Samuel Wells and Ben Quash's Introducing Christian ethics (2010) contains male pronouns and metaphors in reference to God. This is not an exhaustive list. A quick search on the websites of theological journals in the South African context and abroad in the last 20 years will reveal the prevalence of gender-exclusive language. Gender-exclusive language is not restricted to published and academic theology. It is also very prevalent in church hymns and liturgies (cf. Dijk 1998:395; Vermeulen 2016, 2018). Notable is that the justification for exclusive language here is also that inclusive language is too artificial or forced (Vermeulen 2016:1-2 of 9, 2018:1-3 of 9). Profound changes and creative contributions are required towards this 'unfinished dimension of theology' (Ackermann 1994:197). The effect of a nearly 2000-year-old theology derived from male scholarship and experience is not adequately dealt with when gender-inclusive language is brushed off as artificial and viewed as a matter of concern to only a few people (United Methodist Church's task force on language guidelines 1990:5). This will be elaborated from women's theological perspectives, which in this article broadly includes both feminist and womanist theological perspectives.

\section{A 'not-so-brief' word about gender}

Despite years of feminist critique and claims from feminist opposition that 'he' can be used of God without implying

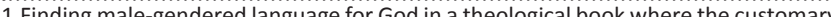
patriarchal ' $m$ ankind' in patriarchal "mankind" in reference to humanity does not appear is surprising and curious. This points to some level of awareness by Nurnberger. The use of 'mankind' and male-gendered pronouns for God usually mutually implies one another and is an indication of the departure point of an author. maleness, the evidence is that feminist concerns are still peripheral, while androcentric God-imagery sustains its primacy. (McIntosh 2007:250)

Feminist, womanist and postcolonial theologians from all over the world have been questioning gender-exclusive theological language for more than four decades. ${ }^{2}$ This endeavour has included the exposure and critique towards male-gendered imagery and metaphors for God, malegendered grammar for God and exclusive gendered language in reference to humanity. It includes creating awareness about the culture the language was formulated in (patriarchy), and provided critical perspectives on the notion of 'objective history'. It presented serious challenges to a history and theology derived exclusively from male (and mostly white) experience and subsequently created awareness of the varying contextual experiences of a diversity of people worldwide, and the correlation between experience, language and the reality that language creates, and, finally, provided different starting blocks, arguments and suggestions towards changing practice. The combined research stated categorically that not all people (in a religious context) will associate a male gender designation with the noun 'God' (cf. Ackermann 1994, 2003; Britto 2005; Carter-Hayward 1982; Chopp 1991; Daly 1973; Dreyer 1998; Dube 2001, 2012; Johnson 1992; Johnson \& Rakoczy 1997; Kanyoro 2001; LenkaBula \& Makofane 2008; Lerner 1986; McFague 1983; Oduyoye 1986; Pui-Lan 2000; Radford-Ruether 1983; Rakoczy 2004; Schüssler-Fiorenza 1983; Spivak 2006; Williams 1993). ${ }^{3}$ In this regard, women's theology has developed into a substantial and independent discourse (cf. Osiek 1997:956).

In tandem with the more than four decades of research, comments, arguments and proposals, there has been a justification of gender-exclusive language and imagery and there is opposition towards any attempt to make confessions, liturgies, hymns, sermons, theology and research representative of the whole of humanity, and all of God's characteristics (cf. Swart \& Coetzee 2013; Wood 2015 - see footnote 4). These arguments are not only solely based on the 'forced nature' of gender-inclusive language, but also include reasoning towards the idea that gender-exclusive language is harmless. According to Esther McIntosh (2007), gender-exclusive language and opposition to alternatives are persistent because in the faith frameworks of many, 'traditional God language implies erroneously both that God is necessarily male and stereotypically masculine' (McIntosh 2007:236). However, theologians from a variety of disciplines and theological perspectives have emphasised that God does not have a gender and that human language is not adequate to describe an entity that is beyond our frame of reference (cf. Bonhoeffer 1967:360; Buber ([1953] 1988:16-17; Dreyer

2.In fact, the use of gender-inclusive language became practiced since the 1960 s coinciding with the second feminist wave (Mezit 2011:16).

3.This is by no means an exhaustive list. It does not include the thousands of articles that have been published on these topics and it does not include all the different works of the theologians that are referenced in the text. For a list of contributions works of the theologians this regard (which goes up to 2002 and 2003 respectively), see the list in Ackermann (2003:57-63) and the ext on this topic after 2003 has increased exponentially and includes increasingly multidisciplinary and interdisciplinary work (see Hendriks et al. 2012: Sociology and Theology; Mezit 2011: Foreign Languages and Translation; Education; Stout 2009 Psychology; Van Wyk 2015, 2017: Political Theology). 
1998:544-572; Johnson 1992; Wood 2015:9 of 10). ${ }^{4}$ Theologians from a variety of disciplines and theological backgrounds are very much aware of the patriarchal context the biblical texts originated in (cf. McGrath 2017:175-177). Yet, genderexclusive language persists and in some cases are justified (Nürnberger 2016a:xxiv; Vermeulen 2016:1-3 of 9). Why is this so? To be able to consider this issue, a broad overview of issues related to language, linguistics and theology will be presented in the next section.

\section{Language, linguistics and how it matters}

According to the postmodern literary theory of philosopher Pierre Bordieu, language has a few main 'functions': it is a system for communication, an instrument of power and it legitimises conduct. Language can empower and strengthen identity. In this regard, there is a 'two-way movement' between 'language' and 'reality': a person's relational position in a given social space determines their language and the relevant social paradigm can determine whose opinion is accepted as reliable, who can be listened to, who can ask questions and who may not ask questions (Bourdieu 1991:215; cf. Geyser-Fouche 2016:2 of 9). This is connected to the debate among philosophers and linguists about whether humanity creates language or if humanity's reality is created by language (cf. Bourdieu 1991; Carson 1998; Luckmann \& Berger 1966). In their reader about postcolonial studies, Ashcroft, Griffiths and Tiffin (2006:261-262) argue that language provides the terms by which a reality may be constituted and it provides the names by which that reality may be known. In this regard, one of the subtlest demonstrations of the power of language is the way in which it provides, by the function of naming, a technique for understanding a place and to have control over it. To name reality is to exert power over it, in the way, for example, European historical formations determined the word 'Africa' as designate for a whole complex of linguistic cultural and economic factors. The power of language is neither vague nor abstract.

Language is used to express social norms and, therefore, it is a crucial instrument for sharing views and ideologies with other humans. As such, it is also a vehicle for gender ideology (Mezit 2011:5). According to Chopp (1991:12), language is both the material and the frame for discussions about the different roles of genders, that is, language creates and shapes beliefs regarding gender (Spender 1998):

It could be said that out of nowhere we invented sexism, we created the arbitrary and approximate categories of male-as-norm and female as deviant. A most original, imaginative creation. But, having constructed these categories in our language and thought pattern, we have now been trapped for we are most reluctant to

4.Wood (2015:9 of 10) acknowledges that human language and symbols restrict our ability to speak about God. Therefore, exclusive language does not necessarily
include or permit women's subordination. She also states that substituting malegendered language and images for female language and images would then exclude males. In this article, I am not arguing for the replacement of exclusive malegendered language for God and humanity by female-gendered language. I am critical towards the persistence of gender-exclusive language. Wood's arguments unfortunately contribute to this persistence because it does not acknowledge the unfortunately contribute to this persistence because it does not acknowledge the
link between language and the construction of reality (cf. the classic work by Berger \& Luckmann 1966 and pertinent sections within this article). organize the world any other way. Indeed, it could even be argued that the trap which we have made is so pervasive that we cannot envisage a world constructed on any other lines. (p. 96)

In this regard, language does not only create and shape beliefs about gender, but language also maintains it. I will now briefly consider different aspects of the discussion and debate about 'language and gender' in relation to religion. For the purposes of this article, the focus is on theology.

\section{Inclusive and exclusive language}

One of the most common arguments in favour of 'exclusive language' is that it is inclusive. This is pointed out by Stout (2009) in her master's thesis, entitled 'When "he" does not mean "you": Gender-exclusive language as a subtle form of ostracism'. According to Eckert and McConnel-Ginet (2003:30), the most problematic characteristic of the English language $\mathrm{e}^{5}$ is the custom to use the male pronoun in the thirdperson singular when referring to persons whose object is unknown or objects that do not have a gender in this particular language. It also happens quite often in the Afrikaans language. Anything from a table to a car to an organisation or company is generally referred to using the male pronoun in third-person singular (hy) (cf. Vermeulen 2016, 2018). Eckert and McConnal-Ginet (2003:30-33) also point out that the request by feminists (and womanist and feminist theologians) to replace 'he' with 'he or she' or 'they' is brushed off as 'pronoun envy' (cf. Stjerna 2016:17). This is connected to the argument that 'he' is sex-indefinite.

My own personal experience corresponds with this. One of the most common retorts to an argument towards genderinclusive language I have heard while teaching at a university and attending Sunday services (with regard to sermons, hymns and liturgies) has been that God as ' $\mathrm{He}^{\prime}$ and human beings as 'mankind' are generic terms, which is inclusive of God's total being and of humankind. This is what I (and others, cf. Stjerna 2016; Stout 2009) would describe as 'exclusive language'. It is exclusive because not only do women feel ostracised when faced with this type of language, they also cannot identify with whatever person, Being or reality the language is used to refer to (Stout 2009:1-2). ${ }^{6}$

5.A question could certainly be asked about the focus on the English language in this article. The first answer to that question would be that Nürnbergers's text is written in English, and that it is the article's 'case in point'. Furthermore, the English language (justifial , a the (justifiable or not) is one of the lingua franca's of the world. During a conference in Hong Kong in 2017, I asked a Chinese theologian about his continued use of the male pronoun in reference to 'God' during his lecture which he delivered in English. He gave me a brief lecture on a paper napkin about Chinese symbols or letters and said it is the English language problem and not theirs. This took place during the 500th commemoration of the Reformation, and therefore his statements, in a year focused on the reformation of church and society, were somewhat disturbing. The exact same thing was explained to me by the Hungarian theologians during said conference. It is a problem, however, because they did not speak Chinese or Hungarian at that conference. It is also a problem because the English language provides other options for speaking inclusively and these were not considered as an option. This underscores the research issue of this article, namely that if alternatives are available in language to speak inclusively, why not make use of them? This includes using the plural pronoun 'they' in reference to humanity or 'God' in reference to God. These questions are also at the foundation of a research article about gender-inclusive language in the Finnish language (cf. Stjerna 2016:17-21).

6.As indicated previously in reference to the work of Bourdieu (1991), group As indicated previously in reference to the work of Bourdieu (1991), group
membership is conveyed linguistically. Gender-exclusive language falls into the category of group-based ostracism. Ostracism refers to ignoring or excluding certain groups or individuals, whereas rejection refers to an explicit declaration of dislike groups or individuals, whereas rejection refers to an explicit declaration of dislike
towards an individual. Language like this makes reference to only a single gender group, thereby excluding the second gender group (Stout 2009:3-4). 
In this regard, it is important to note Carter-Heyward's (1982:11-12) argument about the intrinsic relational capacity of language, which is a matter of bridging self to the other on the basis of common assumptions. Because of this capability or function of language, the importance of the words with which we express our experiences of God cannot be overstated. Language is a primary vehicle of communicating values and commitments, and it is a primary vehicle of communicating ourselves in relation to each other and to that which we may call God. In this regard, language is central to human existence. To speak, or write, to frame or utter a word, is to carry responsibility for what we do and do not do in our relations. It is to reveal, make visible or audible, that which needs expression among us. To form a word is to incarnate something that is real for us. Therefore, language should not be used lightly without recognition of its power to sustain or break human relations. Theological language is no exception. To the contrary, if theological language is symbolically revelatory of that which we value most highly, it must be used carefully in recognition of the power we and others grant it in our lives (Carter-Heyward 1982:13).

\section{The Bible, translation and hermeneutics}

In his book, The inclusive language debate, Carson highlights the complicated nature of Bible translation. He goes as far as comparing this multifaceted task to 'road rage' (Carson 1998:15), in which people drive for thousands of kilometres, someone cuts them off and somehow one final incident of being cut off pushes the driver over 'the edge' - and out comes the crowbar and the shotgun and the result is chaos. The point Carson makes is that Bible translations are not always met with serene acceptance. The task of translating 'gender and sex' in the Bible is even more divisive, and is described by Carson (1998:77) as a 'translators' nightmare'. From my overview of this specific chapter in his book (which is very technical indeed and would require an article devoted this topic alone), the heart of the 'nightmare' revolves around mainly two problems. The first one is how 'gender' is understood and utilised in the 'donor' language and the 'receptor' language. For example, Hebrew and English do not have the same gender systems; Greek and English do not have the same gender systems. An exact 'mirror' replica of gendered language is therefore many times not advisable (Carson 1998:91-98). The second problem, and this is a recurring and a prominent one because of English being one of the main lingua franca's of the world, is that the English language has a pronominal gender system (that is, 'gendered pronouns'; the language does not have a third-person singular common-gender pronoun). For a complete and technical breakdown of the science of translation and Bible translation in particular, see Carson's (1998) book, The inclusive language debate: A plea for realism, and also see Mezit (2011:31-34).

This article is not about an argument towards a re-translation or a re-writing of the Bible. This is one of the aspects of Nürnberger's justification for his use of gender-exclusive language. The biblical texts were written and assembled in a culture that did not value the humanity and worth of anything and anyone outside a norm (cf. Dreyer 2006, 2007). However, it is problematic if the culture the biblical texts were formulated in becomes the norm for language (and therefore, interpretation) about God's nature and being (cf. Stjerna 2016:17-18). It is furthermore problematic if this is used to derive categories for what it means to be human and it is used to create language categories into which all people, irrespective of difference, should fit. This becomes an acute problem if these categories are passed on in theological academic books, like those by Nürnberger, which has the potential to be prescribed to theology students and influence them accordingly. For this reason, it is important to be aware of the role of hermeneutics in the translation of biblical (religious) documents. Elsewhere (cf. Van Wyk 2015:1 of 8) I have used the term 'hermeneutics of suspicion' (in reference to Paul Ricoeur) to refer to the power interests behind the formulation of any type of text, including 'life' as a text.

\section{Language as an instrument of oppression or justice}

Landman (2006:283) asks if 'justice (can) be embodied in sexist language'. Her question is focused on the language of the Belhar Confession and as such is contextual. But the question is an indication of the instrumental power language can yield. Any account of theological language needs to include an acknowledgement that some persons' voices are not recognised (Hector 2011:267). The authority of women and others, outside a white, male norm (cf. Vermeulen 2018) to contribute to God-talk, has for the greater part gone unrecognised and in this regard, they have become theologically invisible (Schüssler-Fiorenza 1996:162). As Hector (2011:267) points out, 'this silencing is not always overt, since the non-recognition at issue can also take the form of recognizing a persons' voice only it if reinforces certain norms'. This underscores Thistlethwaite's (1989; cf. Wren 1989:24) argument that 'linguistic visibility or linguistic invisibility' is much more of an accurate indicator of what is at stake in theological language than the terms 'inclusive' and 'exclusive'. Linguistic visibility affirms the worth of all people (Ackermann 1994:204) and 'until we change the values and hidden rules that run through present linguistic practices, social codes, and psychic orderings, women, persons of colour, and other oppressed groups will be forced - by the language discourses and practices available to them - into conforming to ongoing practices, to babbling nonsense, or to not speaking at all' (Chopp 1991:6-7).

Invisibility and silencing is not the only challenges with regard to theology and language. Contrary to Nürnberger's (2016a:xxiv) claim that all people will identify a male gender with the noun 'God', many people struggle to identify with some of the aspects of prevailing God-talk (Hector 2011:268). If God-talk is controlled by normative concepts and images (cf. Dreyer 2006, 2007) that exclude certain people from identifying with them, these people will not become stewards of this type of language and they will not agree that this type of language includes them or are normative for them. This emphasises some of the previous points made. 
Linguistic invisibility and non-recognition plays a role in perpetuating unjust social arrangements. Linguistic invisibility and non-recognition are used to justify these arrangements and are used to free the beneficiaries of the unjust social arrangements from having to defend their privilege: 'the nonrecognition of certain persons and certain ways of speaking about God can thus serve to perpetuate and justify unequal power relations' (Hector 2011:268). In her research about inclusive language in liturgies, Dijk (1998:395) has illustrated the effect of exclusive liturgical language, namely that it is particularly influential and damaging because of the fact that it functions on a non-cognitive (affective) level. When liturgy repeats unjust power relations 'in the presence of God' and does not provide question marks about these power relations, members of the congregation understand the liturgical language in such a way that unjust relationships seem 'normal' and it strengthens these relationships.

In this regard, patterns of non-recognition are worsened by the fact that the persons from which the recognition is withheld internalise the mechanisms and messages by which they are excluded ${ }^{7}$ and they end up defending the exclusion of persons and their ways of speaking about God. The norms determining the linguistic invisibility are recognised as legitimate (Hector 2011):

\begin{abstract}
... patterns of non-recognition, having been reproduced over and over again through generations, are no longer noticed as such; they come to be seen, if at all, as simply the way things are, as natural - and once the prevailing pattern of recognition has become 'naturalized' in this way, it can be maintained without any overtly coercive activity on anyone's part. (p. 270)
\end{abstract}

This is why gender-exclusive language is persistent and how it maintains a patriarchal church culture. It has become normalised to the point of invisibility. If something is that invisible, how do you even prove it is there? This type of invisibility is addressed by Hillary Rodham Clinton (2017) in her book What happened during the 2016 U.S. election. In her section entitled 'Women and politics', she uses an anecdote (Rodham Clinton 2017:115) to describe this type of invisibility: 'Two young fish are swimming along. They meet an older fish swimming the other way, who nods at them and says, 'Morning boys, how's the water?' The two young fish swim for a bit, until one looks at the other and asks, 'What's water?'

\section{Conclusion: An unfinished reformation - women flourishing in church and society}

In our seeking for truth with a theology that has the power to empower, we need to continue to drill to the core persistently and ask invitingly: what language do we use of God? How do you experience and speak of God? Do you feel free to know and speak of God with your own particular human experience and perspective? In this process, every voice and every pronoun counts, for we are all made in the image and likeness of God. In this regard, the issue of inclusive language is also an issue of justice-a central Christian principle. (Stjerna 2016:18)

7.See Van Wyk (2014) for the functioning of a panopticon.
In 2017, the 500th commemoration of the Reformation was celebrated worldwide. A great many contributions focused on the legacy of the Reformation. For the greater part of the year, there was discussion about Martin Luther, John Calvin, Phillipp Melanchton, Huldrich Zwingli and so on. I attended quite a number of Reformation-inspired events. Not one single time did I hear any of the names of the women who were also part of the Reformation. I made a short study of it and published an article in one of my denomination's publications (Van Wyk 2017b:1). To my count, there were at least 14 women who were key figures during the Reformation. As Lerner (1986:4-5) has pointed out in her work, The creation of patriarchy, there is a distinction between history with a lower case ' $h$ ' and History with an upper case ' $\mathrm{H}$ '. History with a lower case ' $h$ ' is the events of the past. History with an upper case ' $\mathrm{H}$ ' is the recorded and interpreted past - that is, the allocation of 'meaning' to events. In the 'small' history, women have always been present (there), doing whatever it was theirs to do, their part of the work. With 'History-making', however, which came with the advent of writing in ancient Mesopotamia, rulers and their scribes decided which events to be recorded, in which order, in what manner (language; imagery) and by whom. Women were not a part of 'Historymaking', that is, History with an upper case ' $\mathrm{H}$ '. This is the result of the history of patriarchy, of which most theologians are cognisant of. Language has been and continues to be an instrument in maintaining patriarchal practices and therefore represents a dimension of unfinished reformation of the church. For Stjerna (2016:18), reorienting language about God has become a doctrinal urgency. Inclusive language is a matter of urgency for the relevance of theology for future generations. Renewed language for justification goes hand-in-hand with reforms in God-language (Stjerna 2016:18).

It is interesting that undemocratic societies (even those that claim to be democratic) are characterised by habits of exclusive language. These communities (not unlike our own in South Africa) are characterised by how they grapple with language (and identity). During the past few years of teaching theology at a university, I have adopted the custom of asking students to make a list of their identity markers at the onset of lectures. It started out in 2016 as an exercise with students during a lecture about theological anthropology in order to set the scene for theological questions and debates about 'what makes us human'. Since then, I have employed this technique in different lectures and with different groups. During the time that I have done this, a recurring phenomenon has presented itself. Amid a diversity of students naming a diversity of identity markers such as language, culture, religion, faith, ethnicity, sexuality, familial bond and prioritising them in a diversity of ways, gender would generally also be named as an identity marker - but in my experience, it was not named as an identity marker for male students. These were informal 'experiments', conducted as introduction to some lectures and not done for the purpose of gathering statistics. Nevertheless, a pattern emerged. Some of the female students mentioned 'gender' as one of their identity markers, sometimes at the top of their 
list and sometimes at the bottom. They stated that the order of the list might have changed over time. Not all the female students mentioned gender as an identity marker, but in the course of three years, amid three groups of students annually, however, none of the male students stated 'gender' as one of their identity markers.

At a conference in 2017, I did this exercise with the attendees. The theme of my presentation was the relationship between identity and difference in the church. The attendees were not students. They were mostly pastors and ministers, working in congregations and faith communities. The session was presented twice during follow-on sessions. During the first session, there were a handful of people who listed gender, among others, as an identity marker: two of the men put it at the bottom of their list. One of the women placed it somewhere in the middle of her list. During the second session, gender was not mentioned at all. I suggested it as an identity marker, when no one mentioned it. When the session came to an end, one of the attendees came to me and said he has never thought of or considered his 'maleness' as an identity marker. It is invisible to him.

The question is, why would his gender as male be invisible (not part of how he describes his identity) to him, but my gender as a woman be very much part of who I am, to the extent that I list it at the very top of my identity markers? Could it be my gender as a woman has affected my experience in general and understanding of reality in other or more profound ways than his gender as a man has influenced his experiences and understanding of reality? Women's experience of reality, in general, are affected by their gender in a myriad of ways: their access to education and skills-training, their access to higher learning, the type of work they are allowed to do, the career paths they are allowed admittance into, the salaries they receive, the relationships they have, the roles they are allowed to fulfil, the clothes they wear and physical spaces they have access to (cf. Hendriks et al. 2012). In short, women's gender has an impact on their human flourishing. Claassens (2016:6-7) sites Martha Nussbaum's (1999:40-42) 'capabilities list', which lists core aspects of a quality life (Nussbaum 1999):

(1) Life: The ability to live a normal life, not dying before one's time.

(2) Bodily health and integrity: The ability to have access to adequate food and shelter and health care.

(3) Bodily integrity: The ability to be free from violent assault, including rape and domestic violence. To have opportunities to enjoy one's sexuality.

(4) Senses, imagination, thought and the ability 'to imagine, to think, and to reason': This includes access to education, freedom of expression and religious experience.

(5) Emotions: The freedom to express human emotions such as longing, gratitude and anger without fear of recrimination.

(6) Practical reason: The ability to form one's own conception of what is good and apply it to one's own life.

(7) Affiliation: The ability to form meaningful relationships with others and engage freely in various forms of social interaction
(8) Other species: The ability to show concern and be in relation to animals, plants and nature.

(9) Play: The ability to laugh, play and have time for recreational activities.

(10) Control over one's environment:

(a) The ability to engage in politics, possessing 'the rights of political participation, free speech, and the freedom of association'.

(b) The ability to own property both individually and/or collectively.

(c) The right to seek employment on an equal basis with others. (pp. 41-42)

This article has shown that linguistic invisibility and the normalisation of exclusion and ostracism with regard to women goes hand in hand. Gender ideology and gender roles are maintained by these linguistic practices (Mezit 2011):

By adhering to certain social norms concerning gender roles, we re-do gender again and again ... If an engendering act is not performed by the members of society, male or female, it eventually disappears. For this reason, it is of great significance for those who want to keep the status quo in a certain social system to insist on existing practices, value systems and orders. Not infrequently do institutions, very often religious institutions as well, undertake this task. (p. 4)

As Ndukwe (2015:380) has pointed out, there is a 'seemingly lacklustre' attitude of churches towards attempts by nonchurch structures and organisations to realise (to make a reality of) these aspects of a quality life - a flourishing life for women. As the world is witnessing a dynamic movement towards listening to women's narratives of ostracism worldwide, as the United Nations have set up different structures and instruments at regional and international levels to realise the goals and vision of the 'Global and African Platforms for Action for gender equality' (cf. UNECA 2014), the efforts of the church seem to be lacking.

'The interpretation of religious texts regarding gender has influenced the lives of women for millennia' (Mezit 2011:01). As such, the persistence of gender-exclusive language as explained (justified) by theologian Klaus Nürnberger is untenable. The integrity of the gospel of inclusive love is at stake here, as it has been for quite some time. In reference to Ndukwe's (2015:379-394) argument about gender inclusivity, I therefore believe that a kairos has come for a status confessionis about gender-exclusive language.

\section{Acknowledgements}

This research is part of the research project 'Reconciling diversity', directed by Dr T. van Wyk, Faculty of Theology and Religion, University of Pretoria. It is a revision of a paper titled 'A "not-so-brief" word about gender: A response to Klaus Nürnberger's choice of God-language', presented during the Klaus Nürnberber Symposium in January 2018 at the Faculty of Theology and Religion, University of Pretoria. 


\section{Competing interests}

The author declares that she has no financial or personal relationships that may have inappropriately influenced her in writing this article.

\section{References}

Ackermann, D.M., 1994, 'Faith and feminism: Women doing theology', in J. De Gruchy \& C. Villa-Vicencio (eds.), Doing theology in context, pp. 197-211, Orbis Books, Maryknoll, NY.

Ackermann, D.M., 2003, After the locusts: Letters from a landscape of faith, Eerdmans, Grand Rapids, MI.

Ashcroft, B., Griffiths, G. \& Tiffen, H., 2006, The post-colonial studies reader, Routledge, London.

Berger, P.L. \& Luckmann, T., 1966, The social construction of reality, Penguin Books, London.

Bonhoeffer, D., 1967, Letters and papers from prison, SCM, London.

Bourdieu, P., 1991, Language and symbolic power, in L. Thompson (ed.), transl. G. Raymond \& M. Adamson, Polity Press, Cambridge.

Britto, F., 2005, 'The gender of God: Judeo-Christian feminist debates', in A. Jule (ed.) Gender and language of religion, pp. 25-40, Palgrave MacMillan, Hampshire.

Buber, M., [1953] 1988, Eclipse of God: Studies in the revelation between religion and philosophy, Humanities Press International, Atlantic Highlands, NJ.

Carson, D.A., 1998, The inclusive language debate. A plea for realism, Baker Books, Grand Rapids, MI.

Carter-Hayward, I., 1982, The redemption of God: A theology of mutual relation, University Press of America, New York.

Chopp, R.S., 1991, The power to speak: Feminism, language, God, Crossroad, New York. Claassens, J.L., 2016, 'The woman as substance and human flourishing: Proverbs
31:10-31 and Martha Nussbaum's capabilities approach', Journal of Feminist Studies in Religion 32(1), 5-19. https://doi.org/10.2979/jfemistudreli.32.1.02

Daly, M., 1973, Beyond God the Father: Toward a philosophy of women's liberation, Beacon Press, Boston, MA.

Dijk, D.J.J., 1998, 'Inclusieve taal in de liturgie', in P. Oskamp \& N. Schuman (eds.), De weg van de liturgie: Tradities, achtergronden, praktijk, pp. 395-406, Meinema, Zoetermeer.

Dreyer, Y., 1998, 'Pastorale interaksie met vroue - Gesien vanuit die beelde wat vir God gebruik word', HTS Theological Studies/Teologiese Studies 54(3\&4), 544-572.

Dreyer, Y., 2006, 'Heteronormativity, homophobia and homosexuality - Mapping for an inclusive church', HTS Theological/ Teologiese Studies 62(2), 445-471.

Dreyer, Y., 2007, 'Hegemony and the internalisation of homophobia caused by heteronormativity', HTS Theological/ Teologiese Studies 63(1), 2-18. https://doi. org/10.2979/jfemistudreli.32.1.02

Dube, M. (ed.), 2001, Other ways of reading the Bible: African women and the Bible Society of Biblical Literature, Atlanta, GA.

Dube, M., 2012, 'Toward a post-colonial feminist interpretation of the Bible', in W.T. Cavanaugh, J. Bailey \& C. Hovey (eds.), An Eerdmans reader in contemporary political theology, pp. 585-600, Eerdmans, Grand Rapids, MI.

Eckert, P. \& McConnell-Ginet, S., 2003, Language and gender, Cambridge University Press, Cambridge.

Geyser-Fouche, A., 2016, 'Exclusive language: The tool to empower and create identity', Verbum et Ecclesia 37(1), a1495. https://doi.org/10.4102/ve.v37i1.1495

Hector, K., 2011, Theology without metaphysics: God, language and the spirit of recognition, Cambridge University Press, Cambridge.

Hendriks, J.H., Mouton, E., Hansen, L. \& Le Roux, E., 2012, Men in the pulpit, women in the pew?, SunMedia, Stellenbosch.

Johnson, E.A., 1992, She who is: The mystery of God in feminist theological discourse, Crossroad, New York.

Johnson, E.A. \& Rakoczy, S., 1997, Who do you say that I am?, Cluster Publications, Pietermaritzburg.

Kanyoro, M.R.A., 2001, 'Engendered communal theology: African women's contribution to theology in the 21st century', in N.J. Njoroge \& M.W. Dube (eds.), Talitha cum Theologies of African women, pp. 158-180, Cluster Publications, Pietermaritzburg.

Landman, C., 2006, 'Can justice be embodied in sexist language? A challenge to the confession of Belhar', Stellenbosch Theological Journal 41(1-2), 283-290.

LenkaBula, P. \& Makofane, K,M., 2008, Women's agency, governance and the quest for justice in Africa, University of South Africa, Pretoria.

Lerner, G., 1986, The creation of patriarchy, Oxford University Press, Oxford

McFague, S., 1983, Metaphorical Theology: Models of God in religious language, SCM Press, London.

McGrath, A.E., 2017, Christian Theology: An introduction, Wiley Blackwell, Oxford.
McIntosh, E., 2007, 'The possibility of a gender-transcendent God: Taking Macmurray forward', Feminist Theology 15(2), 236-255. https://doi.org/10.1177/096673500 7072034

Mezit, L., 2011, 'Language, gender and religion: An investigation into some genderspecific issues in religious texts, and the impact of language on the role of women in Judaism, Christianity and Islam', Master's thesis in English, University of Agder, viewed 20 May 2018, from https://brage.bibsys.no/xmlui/handle/11250/139286

Ndukwe, O., 2015, 'Gender equality: A kairos for status confessionis or processus confessionis?', in E. Mouton, G. Kapuma, L. Hansen \& T. Togom (eds.), Living with dignity: African perspectives on gender equality, pp. 379-394, Sun Media, Stellenbosch.

Nussbaum, M.C. (ed.), 1999, 'Women and cultural universals', in Sex and socia justice, pp. 39-42, Oxford University Press, Oxford.

Nürnberger, K., 2016a, Faith in Christ today. Invitation to systematic theology: Life in the presence of God, vol. 1, Cluster Publications, Pietermaritzburg.

Nürnberger, K., 2016b, Faith in Christ Today. Invitation to systematic theology: Involved in God's project, vol. 2, Cluster Publications, Pietermaritzburg.

Oduyoye, M.A., 1986, Hearing and knowing: Theological reflections on Christianity in Africa, Orbis Books, Maryknoll, NY.

Osiek, C., 1997, 'The feminist and the Bible: Hermeneutical alternatives', HTS Teologiese Studies/Theological Studies 53(4), 956-968. https://doi.org/10.4102/ hts.v53i4.1753

Pui-Lan, K., 2000, Introducing Asian feminist theology, Pilgrim Press, Cleveland, OH.

Radford-Ruether, R., 1983, Sexism and God-talk: Towards a feminist theology, Beacon Press, Boston, MA

Rakoczy, S., 2004, In her name: Women doing theology, Cluster Publications, Pietermaritzburg.

Rodham-Clinton, H., 2017, What happened?, Simon \& Schuster, New York.

Schüssler-Fiorenza, E., 1983, In memory of her: A feminist theological reconstruction of Christian origins, Crossroad, New York.

Schüssler-Fiorenza, E., 1996, 'Breaking the silence - Becoming visible', in E. SchüsslerFiorenza (ed.), The power of naming: A concilium reader in feminist liberation theology, pp. 160-163, Orbis Books, Maryknoll, NY.

Spender, D., 1998, 'Excerpts from man made language', in D. Cameron (ed.), The feminist critique of language: A reader, pp. 93-99, Routledge, Abingdon \& New York.

Spivak, G.C., 2006, 'Can the subaltern speak?', in B. Ashcroft, G. Griffiths \& H. Tiffin (eds.), The post-colonial studies reader, pp. 28-38, Routledge, New York.

Stjerna, K., 2016, 'Ongoing reformation of language and spirituality: Intersections with the Finnish interpretation of Luther and feminist scholarship', Currents in Theology and Mission 43(3), 17-21.

Stout, J.G., 2009, 'When "he" doesn't mean "you": Gender exclusive language as subtle ostracism', Master's thesis, University of Massachusetts, Amherst, MA.

Swart, A.E. \& Coetzee, C.F.C., 2013, 'Die Skrifbeskouing van feministiese teoloë, in die besonder dié van Fiorenza, Brenner en Van Dijk-Hemmes: Beoordeel in die lig van die gereformeerde teologie', In die Skriflig/In Luce Verbi 47(1). https://doi.org/ 10.4102/ids.v47i1.1686

Thiselton, A., 2015, Systematic theology, Eerdmans, Grand Rapids, MI.

Thistlethwaite, S., 1989, Sex, race and God: Christian feminism in black and white, Crossroad, New York.

UNECA (United Nations Economic Commission for Africa), 2014, 'Recent trends in national mechanisms for gender equality in Africa', viewed 24 May 2018, from https://www.uneca.org/sites/default/files/PublicationFiles/report-cwd.pdf

United Methodist Church's task force on language guidelines, 1990, Words that hurt, words that heal: Language about God and people, Grade Press, Nashville, TN.

Van Wyk, T., 2014, 'Church as Heterotopia', HTS Teologiese Studies/Theological studies 70(1), Art. \#2684, 7 pages.

Van Wyk, T., 2015, 'Political Theology as critical theology', HTS Teologiese Studies/ Theological Studies 71(3), Art. \#3026, 8 pages.

Van Wyk, T., 2017a, 'Let us play: (un)schackling liaisons, (un)masking games and (un) hindered dialogue in the arena where theology takes place', in 'Ecodomy - Life in its fullness', Verbum et Ecclesia 38(3), a1659. https://doi.org/10.4102/ve.v38i3.1659

Van Wyk, T., 2017b, 'Vroue van die Reformasie', Die Hervormer 108(10), 1-2.

Vermeulen, O.C., 2016, 'Agter elke man: Onderweg na inklusiewe taalgebruik in die Afrikaanse kerklied', HTS Teologiese Studies/ Theological Studies 72(3), a3043. https://doi.org/10.4102/hts.v72i1.3043

Vermeulen, O.C., 2018, 'Onderweg na inklusiewe taalgebruik in die Afrikaanse kerklied (2): Die heteroseksuele witman as God', HTS Theological Studies/ Teologiese Studies 74(4), 4764. https://doi.org/10.4102/hts.v74i4.4764

Wells, S. \& Quash, B., 2010, Introducing Christian ethics, Wiley Blackwell, Oxford.

Williams, D.S., 1993, Sisters in the wilderness: The challenge of womanist God-talk, Orbis Books, Maryknoll, NY.

Wood, H., 2015, 'Revisiting Mary Daly: Towards a quadripartite theological and philosophical paradigm', HTS Teologiese Studies/ Theological Studies 71(1), Art. 2911, 10 pages.

Wren, B., 1989, What language shall I borrow? God-talk in worship: A male response to feminist theology, SCM Press, London. 